Editorial

\title{
Rare Earth and Actinide Complexes
}

\author{
Stephen M. Mansell ${ }^{1, *}$ and Stephen T. Liddle ${ }^{2, *}$ \\ 1 Institute of Chemical Sciences, School of Engineering and Physical Sciences, Heriot-Watt University, \\ Edinburgh, EH14 4AS, UK \\ 2 School of Chemistry, The University of Manchester, Oxford Road, Manchester, M13 9PL, UK \\ * Correspondences: s.mansell@hw.ac.uk (S.M.M.); steve.liddle@manchester.ac.uk (S.T.L.); \\ Tel.: +44-131-451-4299 (S.M.M.); +44-161-275-4612 (S.T.L.)
}

Academic Editor: Duncan H. Gregory

Received: 4 October 2016; Accepted: 12 October 2016; Published: 14 October 2016

The rare earth metals (scandium, yttrium, lanthanum and the subsequent $4 \mathrm{f}$ elements) and actinides (actinium and the $5 \mathrm{f}$ elements) are vital components of our technology-dominated society. Examples include the fluorescent-red europium ions used in euro banknotes to deter counterfeiting [1], the radioactive americium used in smoke detectors [2] that save countless lives every year as well as neodymium used in the strongest permanent magnets [3]. However, the rare earth and actinide elements remain poorly recognised by non-scientists, and even by many undergraduates in chemistry.

The similar radii of the respective +3 cations (Figure 1) belies their individually unique spectral [4] and magnetic [5] properties that contribute to their fascinating chemistry. In this Special Issue, devoted to molecular rare earth and actinide complexes, work from Natrajan and co-workers [6] has explored how fluorinated ligands improve the luminescence of $4 \mathrm{f}$ complexes, while Baker and co-workers [7] investigated the optical properties, as well as structure, of a new class of uranyl selenocyanate. Pointillart and co-workers' article [8] bridges the areas of lanthanide optical and magnetic properties-literally—by using bridging tetrathiafulvalene derivatives. The growing field of Single Molecule Magnetism originates in the d-block, but recent interest in the f-elements has been growing. Powell and co-workers [9] explore the use of dimeric dysprosium (which has a highly anisotropic f-electron distribution) compounds with a "hula-hoop" geometry, defined by the ligand that sits in an equatorial plane around both Dy atoms. The main current medical use for the lanthanides, as Magnetic Resonance Imaging (MRI) contrast agents, also relies on the unique electronic properties of the lanthanides. The article by Parac-Vogt and co-workers [10] demonstrates the combination of gadolinium for MRI imaging (thanks to its seven unpaired electrons) connected to a luminescent BODIPY fragment in order to explore combined MRI and optical imaging, addressing the drawbacks of both techniques through their complementary properties.

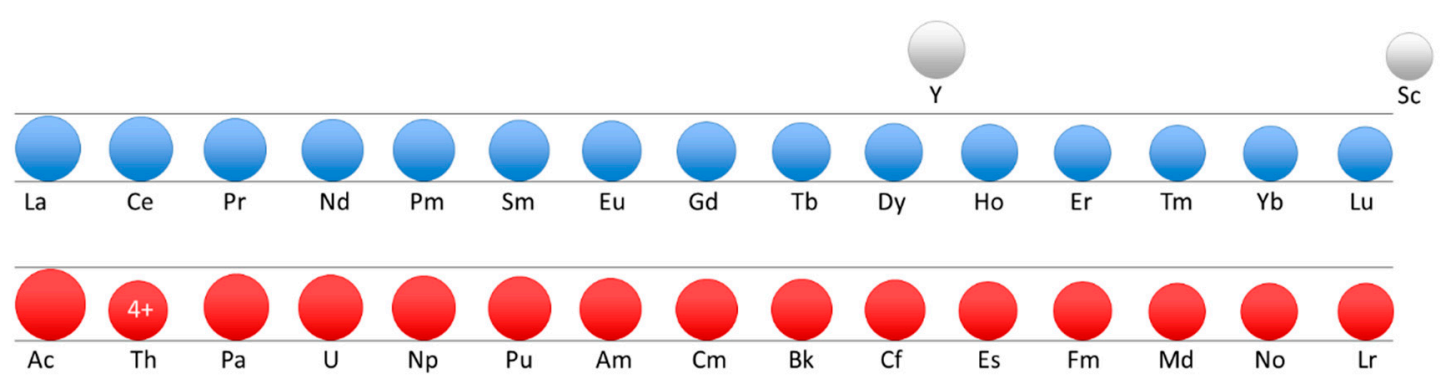

Figure 1. The ionic radii of the 6-coordinate $\mathrm{M}^{3+}$ cations of the rare earth and actinide metals (except for Th which is $\mathrm{Th}^{4+}$ ) [11-13].

Another growing application of molecular lanthanide complexes is in catalysis, and in this issue, Kostakis and co-workers [14] report the use of lanthanide coordination polymers as catalysts in 
a domino reaction. As with the d-block, organometallic lanthanide chemistry has proven to be of vital use in the development of homogeneous catalysis. This issue reflects this growing interest with papers demonstrating the synthesis of organometallic lanthanide complexes using imide (Anwander and co-workers) [15], amidinate (Edelman and co-workers) [16], reduced bipyridine (Mills and co-workers) [17] and metallocene ( $\mathrm{Ce}^{4+}$ complexes by Gordon and co-workers [18], the reactivity of $\mathrm{Sm}^{2+}$ by Maron and co-workers [19] and $\mathrm{U}^{3+} / \mathrm{U}^{4+}$ bromides by Kiplinger and co-workers [20]) ligand frameworks. A review from Eisen and co-workers [21] is devoted to actinide catalysis and an article from Visseaux and co-workers [22] details the extension of organometallic Nd catalysis into the solid state demonstrating the numerous current applications of these interesting species. The review by Turner [23] highlights $\mathrm{N}_{2}$ and $\mathrm{P}_{4}$ activation chemistry of the f-block, an area of great future catalytic potential.

We hope you will enjoy the breadth of chemistry offered in this open access Special Issue that highlights the many differences between complexes of the rare earths and actinides. However, the similarity of ionic radii is inescapable for the +3 oxidation state, which gives rise to one of the most challenging remaining problems for f-block chemists and the potential renaissance of nuclear power (as well as tackling historical problems). The separation of highly radioactive and frustratingly long-lived heavier actinides from shorter-lived radioactive isotopes of the lanthanides would greatly aid planning for the long-term storage of nuclear waste. It is promising that the current resurgence of interest in the fundamental chemistry of the f-block can feed into the goal of discriminating between the actinides and lanthanides based on differences in bonding and reactivity thereby boosting efforts in the area of nuclear waste separation and storage. In fact, the article by Beekmeyer and Kerridge compares covalency in $\left[\mathrm{CeCl}_{6}\right]^{n-}$ and $\left[\mathrm{UCl}_{6}\right]^{n-}$ as a means of shedding light on this very problem [24]. We look forward to many more academic and practical advances in all of the above fields of research in the near future.

\section{References}

1. Rare Earths: Neither Rare, Nor Earths. Available online: http://www.bbc.co.uk/news/magazine-26687605 (accessed on 30 September 2016).

2. Smoke Detectors and Americium. Available online: http://www.world-nuclear.org/informationlibrary/non-power-nuclear-applications/radioisotopes-research/smoke-detectors-and-americium.aspx (accessed on 30 September 2016).

3. Brown, D.N. Fabrication, processing technologies, and new advances for RE-Fe-B magnets. IEEE Trans. Magn. 2016, 52, 1-9. [CrossRef]

4. Bünzli, J.-C.G.; Piguet, C. Taking advantage of luminescent lanthanide ions. Chem. Soc. Rev. 2005, 34, 1048-1077. [CrossRef] [PubMed]

5. Sessoli, R.; Powell, A.K. Strategies towards single molecule magnets based on lanthanide ions. Coord. Chem. Rev. 2009, 253, 2328-2341. [CrossRef]

6. Swinburne, A.; Langford Paden, M.; Chan, T.; Randall, S.; Ortu, F.; Kenwright, A.; Natrajan, L. Optical properties of heavily fluorinated lanthanide tris $\beta$-diketonate phosphine oxide adducts. Inorganics 2016, 4, 27. [CrossRef]

7. Nuzzo, S.; Browne, M.; Twamley, B.; Lyons, M.; Baker, R. A structural and spectroscopic study of the first uranyl selenocyanate, $\left[\mathrm{Et}_{4} \mathrm{~N}_{3}\left[\mathrm{UO}_{2}(\mathrm{NCSe})_{5}\right]\right.$. Inorganics 2016, 4, 4. [CrossRef]

8. Pointillart, F.; Speed, S.; Lefeuvre, B.; Riobé, F.; Golhen, S.; Le Guennic, B.; Cador, O.; Maury, O.; Ouahab, L. Magnetic and photo-physical properties of lanthanide dinuclear complexes involving the 4,5-bis(2-pyridyl-N-oxidemethylthio)-4', $5^{\prime}$-dicarboxylic acid-tetrathiafulvalene-, dimethyl ester ligand. Inorganics 2015, 3, 554. [CrossRef]

9. Peng, Y.; Mereacre, V.; Anson, C.; Powell, A. Tuning of hula-hoop coordination geometry in a Dy dimer. Inorganics 2016, 4, 2. [CrossRef]

10. Ceulemans, M.; Nuyts, K.; De Borggraeve, W.; Parac-Vogt, T. Gadolinium(III)-DOTA complex functionalized with BODIPY as a potential bimodal contrast agent for MRI and optical imaging. Inorganics 2015, 3, 516. [CrossRef] 
11. Shannon Effective Ionic Radii. Available online: http://v.web.umkc.edu/vanhornj/shannonradii.htm (accessed on 10 October 2016).

12. Bilewicz, A. The ionic radius of $\mathrm{No}^{3+}$. J. Nucl. Radiochem. Sci. 2002, 3, 147-149. [CrossRef]

13. Bilewicz, A. Ionic radii of heavy actinide(III) cations. Radiochim. Acta 2004, 92, 69-72. [CrossRef]

14. Loukopoulos, E.; Griffiths, K.; Akien, G.; Kourkoumelis, N.; Abdul-Sada, A.; Kostakis, G. Dinuclear lanthanide (III) coordination polymers in a domino reaction. Inorganics 2015, 3, 448. [CrossRef]

15. Schädle, D.; Maichle-Mössmer, C.; Törnroos, K.; Anwander, R. Holmium(III) supermesityl-imide complexes bearing methylaluminato/gallato ligands. Inorganics 2015, 3, 500. [CrossRef]

16. Sroor, F.; Hrib, C.; Edelmann, F. New lanthanide alkynylamidinates and diiminophosphinates. Inorganics 2015, 3, 429. [CrossRef]

17. Ortu, F.; Zhu, H.; Boulon, M.-E.; Mills, D. Synthesis and reactivity of a cerium(III) scorpionate complex containing a redox non-innocent 2,2'-bipyridine ligand. Inorganics 2015, 3, 534. [CrossRef]

18. Sutton, A.; Clark, D.; Scott, B.; Gordon, J. Synthesis and characterization of cerium(IV) metallocenes. Inorganics 2015, 3, 589. [CrossRef]

19. Kefalidis, C.; Maron, L. On the dehydrocoupling of alkenylacetylenes mediated by various samarocene complexes: A charming story of metal cooperativity revealing a novel dual metal $\sigma$-bond metathesis type of mechanism (DM $\mid \sigma-\mathrm{BM})$. Inorganics 2015, 3, 573. [CrossRef]

20. Lichtscheidl, A.; Pagano, J.; Scott, B.; Nelson, A.; Kiplinger, J. Expanding the chemistry of actinide metallocene bromides. Synthesis, properties and molecular structures of the tetravalent and trivalent uranium bromide complexes: $\left(\mathrm{C}_{5} \mathrm{Me}_{4} \mathrm{R}\right)_{2} \mathrm{UBr}_{2},\left(\mathrm{C}_{5} \mathrm{Me}_{4} \mathrm{R}\right)_{2} \mathrm{U}\left(\mathrm{O}-2,6-{ }^{i} \mathrm{Pr}_{2} \mathrm{C}_{6} \mathrm{H}_{3}\right)(\mathrm{Br})$, and $[\mathrm{K}(\mathrm{THF})]\left[\left(\mathrm{C}_{5} \mathrm{Me}_{4} \mathrm{R}\right)_{2} \mathrm{UBr}_{2}\right](\mathrm{R}=\mathrm{Me}, \mathrm{Et})$. Inorganics 2016, 4, 1. [CrossRef]

21. Karmel, I.; Batrice, R.; Eisen, M. Catalytic organic transformations mediated by actinide complexes. Inorganics 2015, 3, 392. [CrossRef]

22. Russell, S.; Loiseau, T.; Volkringer, C.; Visseaux, M. Luminescent lanthanide metal organic frameworks for cis-selective isoprene polymerization catalysis. Inorganics 2015, 3, 467. [CrossRef]

23. Turner, Z. Molecular pnictogen activation by rare earth and actinide complexes. Inorganics 2015, 3, 597. [CrossRef]

24. Beekmeyer, R.; Kerridge, A. Assessing covalency in cerium and uranium hexachlorides: A correlated wavefunction and density functional theory study. Inorganics 2015, 3, 482. [CrossRef]

(C) 2016 by the authors; licensee MDPI, Basel, Switzerland. This article is an open access article distributed under the terms and conditions of the Creative Commons Attribution (CC-BY) license (http://creativecommons.org/licenses/by/4.0/). 